KAZIMIERZ BEM

Marlborough, MA, USA

\title{
CZYNNIK WYZNANIOWY W POLITYCE NOMINACYJNEJ STEFANA BATOREGO NA STAROSTWA GRODOWE W KORONIE - POCZĄTEK KONTRREFORMACJI?*
}

\author{
W stęp
}

W dotychczasowej literaturze na zagadnienie wpływów politycznych i pozycji dysydentów (luteranów, kalwinistów, braci polskich i czeskich) w szesnastowiecznej Polsce patrzono zazwyczaj poprzez pryzmat liczebności protestantów zasiadających w senacie ${ }^{1}$. Choć jest to aspekt niewątpliwie ważny i pomocny, to opieranie się wyłącznie na tej statystyce nie jest pozbawione problemów.

Po pierwsze, część kasztelanów drążkowych pełniła do czasów Zygmunta III Wazy także funkcje poselskie ${ }^{2}$ i nie brała udziału w obradach senatu, preferując zasiadanie w izbie poselskiej. Tym samym podczas obrad sejmu reprezentacja dysydentów i ich wpływy w senacie były w rzeczywistości słabsze niżby wynikało to ze statystyk. W przypadku

* Autor chciałby serdecznie podziękować Marii Blackwood z Harvard University oraz Christine Pesch z biblioteki Yale Divinity School za ogromną pomoc w dotarciu do materiałów niezbędnych do napisania tej pracy.

${ }^{1} \mathrm{H}$. Merczyng, Zbory i senatorowie protestanccy $w$ dawnej Rzeczypospolitej, Warszawa 1905; E. Barwiński, Zygmunt III i dysydenci, „Reformacja w Polsce” 1, 1921, 1, s. 51-53; W. Dworzaczek, Oblicze wyznaniowe senatu Rzeczpospolitej Polskiej w dobie kontrreformacji, w: Muneria Literaria. Księga ku czci profesora Romana Pollaka, red. W. Dworzaczek i in., Poznań 1962, s. 41-56; H. Lulewicz, Skład wyznaniowy senatorów świeckich Wielkiego Księstwa Litewskiego za panowania Wazów, PH 68, 1977, 3, s. 425-445; E. Opaliński, Elita władzy w województwach poznańskim i kaliskim za Zygmunta III, Poznań 1981, s. 65; A. K. Banach, Konwersje protestantów na katolicyzm w Koronie w latach 1560-1600, „Zeszyty Naukowe Uniwersytetu Jagiellońskiego. Prace Historyczne” 1985, 77, s. 21-35; L. Jarmiński, Bez użycia siły. Działalność polityczna protestantów w Rzeczpospolitej u schyłku XVI wieku, Warszawa 1992, s. 14-22.

${ }^{2}$ L. Kieniewicz, Senat za Stefana Batorego, Warszawa 2000, s. 136-155. 
senatorów drążkowych, choć oczywiście pełnili oni funkcje senatorskie poza obradami sejmu, to lokalnie dużo większe znaczenie mieli wojewodowie i odpowiedzialni za wykonywanie wyroków sądów starostowie grodowi. Już Leszek Jarmiński sygnalizował, że pokaźna liczba senatorów dysydentów staje się nieco mniej imponująca, gdy od niej odliczymy kasztelanów drążkowych, posiadających najmniejszy prestiż ${ }^{3}$.

Po drugie, frekwencja senatorów na sejmach nie zawsze była wysoka i stąd samo wyliczanie senatorów dysydentów może dawać złudne poczucie ich znaczenia. Podam dwa przykłady: podczas sejmu w $1593 \mathrm{r}$. jedynym wotującym senatorem dysydentem był Andrzej Męciński, choć pod koniec obrad liczba senatorów dysydentów wzrosła do siedmiu ${ }^{4}$. W tym czasie senatorami było 37 protestantów. W obradach sejmu walnego w 1600 r. uczestniczyło 7 biskupów oraz 23 senatorów świeckich, wśród których było zaledwie 3 protestantów (Andrzej Firlej, Jan Wodyński i Krzysztof Dorohostajski), z których dodatkowo kasztelan radomski A. Firlej i K. Dorohostajski spóźnili się i przybyli na sejm już po wotach senatorskich ${ }^{5}$. W tym samym okresie ogólna liczba senatorów protestantów wynosiła 25 osób. Podobnie było podczas innych sejmów.

Dotychczas gros zestawień skupiało się na porównywaniu stanu liczebnego senatorów z początków i z końca panowania Zygmunta III Wazy, na którego rządy przypada gwałtowne kurczenie się wpływów protestantów w strukturach władzy Rzeczypospolitej Obojga Narodów. Na tym tle Stefan Batory i jego panowanie wypadało dość pozytywnie i był on symbolem tolerancyjnego władcy, choć niektórzy historycy starali się tę utartą w historiografii opinię nieco zniuansować6. Tymczasem to okres jego panowania jest ważny, gdyż wtedy właśnie należy umieścić początek działalności kontrreformacyjnej Kościoła rzymskiego w Rzeczypospolitej: począwszy od skutecznego blokowania prób uchwalenia przepisów wykonawczych do Konfederacji Warszawskiej po nasilający się trend odzyskiwania kościołów w Koronie sprotestantyzowanych w poprzednich dekadach.

${ }^{3}$ L. Jarmiński, op. cit., s. 17, 20.

${ }^{4}$ Ibidem, s. 47-52.

${ }^{5}$ A. Radaman, M. Ferenc, Rejestr senatorów i posłów na sejmie walnym warszawskim 9 lutego-21 marca 1600 r., „Zeszyty Naukowe Uniwersytetu Jagiellońskiego. Prace Historyczne" 2004, 131, s. 89-106.

${ }^{6} \mathrm{G}$. Schramm, Der polonische Adel und die Reformation 1548-1607, Wiesbaden 1965, s. 204-209; J. T. Maciuszko, Konfederacja Warszawska 1573 r., Warszawa 1984, s. 197-207; J. Besala, Stefan Batory, Warszawa 1992, s. 70-71, 129, 387, 397-399; W. Kriegseisen, Stosunki wyznaniowe $w$ relacjach państwo-kościót między reformacja a oświeceniem, Warszawa 2010, s. 545-547; U. Augustyniak, Państwo świeckie czy księże? Spór o rolę duchowieństwa katolickiego w Rzeczypospolitej w czasach Zygmunta III Wazy. Wybór tekstów, Warszawa 2013, s. 39-44. 
Jak słusznie zwrócił uwagę Jarmiński, przy analizach znaczenia i wpływów dysydentów w XVI i XVII w. należy przyjrzeć się nie tylko funkcjom senatorskim, ale także urzędowi starostów grodowych w Koronie, gdyż „z uwagi na szeroki zakres sprawowanej władzy mieli oni w terenie dużo większe wpływy niż senatorowie drążkowi"7.

Przedmiotem niniejszej pracy jest próba uzupełnienia spojrzenia na siłę dysydentów w Koronie poprzez dodanie do dotychczasowych zestawień porównania wpływów dysydentów w obsadzie starostw grodowych w Koronie w czasach panowania Stefana Batorego. Za początkową datę przyjąłem moment koronacji monarchy (1 V 1576), za datę końcową zaś datę jego śmierci (12 XII 1586). Z zestawienia wyłączyłem starostwa grodowe na Mazowszu, a więc regionie najsłabiej objętym ruchem reformacyjnym - choć z oczywistych powodów omówiłem nominację Jerzego Niemsty na starostę warszawskiego. Również ze względu na inną specyfikę prawną i społeczną nie zajmowałem się nominacjami na obszarze Wielkiego Księstwa Litewskiego. Do zestawienia dodałem natomiast wojewodów Prus Królewskich oraz wojewodę kijowskiego, gdyż pełnili oni funkcje starostów grodowych na podległych sobie ziemiach. Źródłami, z których korzystałem, były spisy urzędników wydane przez Polską Akademię Nauk, weryfikujące ustalenia Krzysztofa Chłapowskiego ${ }^{8}$, a także biogramy w Polskim Słowniku Biograficznym.

\section{Polityka nominacyjna Stefana Batorego}

Jak już wspomniałem, w Prusach Królewskich, w przeciwieństwie do reszty Korony, funkcję starostów grodowych pełnili tamtejsi wojewodowie, stąd celowe jest przyjrzenie się polityce nominacyjnej monarchy w odniesieniu do tych urzędów. Na trzech wojewodów w tej prowincji ewangelikami u progu 1576 r. byli dwaj luteranie: Fabian Czema (zm. 1580), wojewoda malborski ${ }^{9}$, oraz Achacy Czema (zm. 1576), wojewoda pomorski ${ }^{10}$. Trzecie z województw, województwo chełmińskie, znajdowało się w rękach katolika Jana Działyńskiego (zm. 1583) ${ }^{11}$.

${ }^{7}$ L. Jarmiński, op. cit., s. 23.

${ }^{8}$ K. Chłapowski, Starostowie w Małopolsce 1565-1668, w: Społeczeństwo staropolskie. Studia i szkice, t. 4, red. A. Izydorczyk, A. Wyczański, Warszawa 1986, s. 105-178.

${ }^{9}$ Urzędnicy, t. 5, z. 2: Urzędnicy Prus Królewskich XV-XVIII wieku. Spisy, oprac. K. Mikulski, Wrocław 1990, s. 110; P. Czaplewski, Fabian Czema, PSB, t. 4, Kraków 1938, s. 327-328.

${ }^{10}$ Urzędnicy, t. 5, z. 2, s. 135; P. Czaplewski, Achacy Czema, PSB, t. 4, s. 327.

${ }^{11}$ Urzędnicy, t. 5, z. 2, s. 78. 
W okresie swojego panowania Stefan Batory miał okazję dokonać całkowitej wymiany wojewodów w tej prowincji. Jak więc wyglądała jego polityka nominacyjna? J. Działyńskiego zastąpił katolik, Michał Działyński (zm. 1600) - katolicy utrzymali więc to silnie katolickie województwo ${ }^{12}$. Po śmierci A. Czemy na wojewodę pomorskiego w 1577 r. król mianował gorliwego katolika Krzysztofa Kostkę (zm. 1594). W 1581 r. po śmierci luteranina Fabiana Czemy, wojewody malborskiego, król przekazał urząd jego bratankowi, luteraninowi Fabianowi Czemie (zm. 1605) ${ }^{13}$. Tym samym w ciągu swego panowania monarcha dokonał zupełnego odwrócenia proporcji w tej prowincji - ewangelik dzierżył już tylko województwo malborskie. Biorąc pod uwagę wysoki odsetek protestantów na tych terenach, szczególnie bolesne było odsunięcie ewangelików od funkcji wojewody pomorskiego. Miało się to okazać pomocne później, gdy Kościół rzymski na terenie tego województwa rozpoczął energiczną rewindykację kościołów zamienionych na zbory.

W Wielkopolsce oprócz funkcji starosty generalnego Wielkopolski istniały osobne starostwa w Nakle i Wschowie. Funkcję starostów generalnych pełnili przez całe panowanie monarchy zawsze katolicy: najpierw Wojciech Sędziwój Czarnkowski (zm. 1578) ${ }^{14}$, a potem mianowany przez Batorego katolik (i eksluteranin) Andrzej Opaliński (zm. 1593) ${ }^{15}$. Starostwo nakielskie dzierżyli kolejno katolicy: Stanisław Kościelecki (zm. 1583), a po nim jego brat Krzysztof - kasztelan inowrocławski ${ }^{16}$. Starostwo wschowskie przez cały okres panowania monarchy dzierżył mianowany jeszcze przez Zygmunta II Augusta luteranin Jan Górski (zm.1588) ${ }^{17}$. A zatem w obu przypadkach, gdy zawakowało wielkopolskie starostwo, monarcha powierzył je katolikom, utrzymując ich przewage z okresu sprzed swojego panowania. Ewangelicy pozostali przy starostwie wschowskim tylko dlatego, że pozostawało w rękach tej samej osoby. Choć znajdowało się w regionie silnie sprotestantyzowanym, było to jednak najmniejsze, najsłabiej uposażone i najmniej prestiżowe starostwo w Wielkopolsce ${ }^{18}$.

$\mathrm{Na}$ terenie ziemi kujawsko-dobrzyńskiej znajdowało się w sumie osiem starostw grodowych, przy czym starostwo bobrownickie obejmowało całą i silnie katolicką Ziemię Dobrzyńską. Przez okres panowania

${ }^{12}$ Ibidem.

${ }^{13}$ Urzędnicy, t. 5, z. 2, s. 110; P. Czaplewski, Fabian Czema, s. 328.

${ }^{14}$ Urzędnicy, t. 1, z. 2: Urzędnicy wielkopolscy XVI-XVIII wieku. Spisy, oprac. A. Bieniaszewski, Wrocław 1987, s. 165.

${ }^{15}$ Ibidem.

${ }^{16}$ Ibidem, s. 108.

${ }^{17}$ Ibidem, s. 187.

${ }^{18}$ U. Piotrkowska, Struktura i rozmieszczenie własności feudalnej w województwie poznańskim w 2 połowie XVI wieku, w: Społeczeństwo staropolskie, t. 4, s. 22. 
Stefana Batorego zmieniło ono posiadaczy dwa razy i w obu przypadkach byli to katolicy ${ }^{19}$. Pozostałych siedem starostw grodowych znajdowało się na Kujawach. U progu 1576 r. w rękach katolików znajdowały się trzy starostwa: brzesko-kujawskie ${ }^{20}$, bydgoskie ${ }^{21}$ oraz kruszwickie ${ }^{22}$, z czego dwa pierwsze pozostały w rękach tych samych posiadaczy do końca panowania monarchy. Pozostałe cztery były w rękach ewangelików: Stanisław Latalski (zm. 1598), luteranin, był starostą inowrocławskim (do 1592) ${ }^{23}$, Łukasz Działyński (zm. 1583), luteranin, był starostą kowalskim ${ }^{24}$, Jan Sierakowski (zm. 1589), wojewoda łęczycki, wówczas jeszcze kalwinista, był starostą przedeckim ${ }^{25}$, wreszcie Rafał Leszczyński (zm. 1592), kasztelan śremski i kalwinista, był starostą radziejowskim ${ }^{26}$.

Jak przedstawiała się polityka nominacyjna Stefana Batorego na tych terenach? W $1576 \mathrm{r}$. wyraził on zgodę na cesję starostwa przedeckiego synowi J. Sierakowskiego, Stanisławowi Sierakowskiemu (zm. 1596), kasztelanowi lędzkiemu. Choć ojciec nowego starosty przeszedł jeszcze w tym samym roku na katolicyzm, Stanisław pozostał kalwinistą do końca życia ${ }^{27}$. W 1579 r. monarcha wyraził zgodę na cesję starostwa radziejowskiego synowi R. Leszczyńskiego, Janowi Leszczyńskiemu (zm. 1589). Był on wtedy członkiem Kościoła Braci Czeskich, choć pod koniec kolejnej dekady dokonał konwersji na katolicyzm ${ }^{28}$.W 1582 r. król zezwolił na cesję starostwa kruszwickiego przez katolika Walentego Grodzińskiego na rzecz Adama Balińskiego (zm. 1600), luteranina ${ }^{29}$.W tym samym roku, po śmierci luteranina Ł. Działyńskiego, oddał starostwo kowalskie katolikowi Wojciechowi Ręczajskiemu, kasztelanowi warszawskiemu ${ }^{30}$.Jeśli przyjmiemy datę konwersji starosty radziejowskiego na okres przed 1586 r., w chwili śmierci monarchy pozycja ewangelików na Kujawach uległa lekkiemu osłabieniu,

${ }^{19}$ Urzędnicy, t. 6, z. 2: Urzędnicy kujawscy i dobrzyńscy XVI-XVIII wieku. Spisy, oprac. K. Mikulski, W. Stanek, Kórnik 1990, s. 164.

${ }^{20}$ Ibidem, s. 57.

${ }^{21}$ Ibidem, s. 78.

${ }^{22}$ Ibidem, s. 141.

${ }^{23}$ Ibidem, s. 108.

${ }^{24}$ Ibidem, s. 127, S. Bodniak, Łukasz Działyński, PSB, t. 6, Kraków 1948, s. 89-90.

${ }^{25}$ Urzędnicy, t. 6, z. 2, s. 153; K. Chłapowski, Jan Sierakowski, PSB, t. 37, WarszawaKraków 1996, s. 259-266.

${ }^{26}$ Urzędnicy, t. 6, z. 2, s. 159; M. Sipayłło, Rafał Leszczyński, PSB, t. 17, Wrocław 1972, s. $132-135$.

${ }^{27}$ Urzędnicy, t. 6, z. 2, s. 153; A. Kamieński, Stanisław Sierakowski, PSB, t. 37, s. 299-302.

${ }^{28}$ Urzędnicy, t. 6, z. 2, s. 159.

${ }^{29}$ Ibidem, s. 141.

${ }^{30}$ Ibidem, s. 128; I. Gieysztorowa, Wojciech Ręczajski, PSB, t. 31, Wrocław 1988, s. $240-242$. 
i posiadali teraz trzy starostwa grodowe, wobec czterech w posiadaniu katolików. Zmiana ta była wynikiem nie tyle decyzji monarchy, ile konwersji starosty radziejowskiego J. Leszczyńskiego na katolicyzm.

Jeśli chodzi o województwa łęczyckie i sieradzkie, to u progu 1576 r. ewangelicy dzierżyli trzy z tutejszych pięciu starostw: Baltazar Lutomirski (zm. 1587), członek Kościoła Braci Czeskich, był starostą sieradzkim³1, kalwinista Stanisław Przedbór Koniecpolski (zm. 1588) był starostą wieluńskim ${ }^{32}$, a luteranin Jakub Rokossowski (zm. 1580) starostą ostrzeszowskim $^{33}$. Katolicy dzierżyli wtedy starostwo łęczyckie oraz piotrkowskie ${ }^{34}$, co generalnie pokrywało się z mapą zborów ewangelickich w tym regionie. Przez całe panowanie Stefana Batorego nie uległy zmianom obsady w starostwie sieradzkim i piotrkowskim, natomiast aż trzy razy monarcha dokonał roszad w starostwie łęczyckim. Początkowo król dwukrotnie mianował tam katolików, ale w 1583 r. zgodził się na cesję starostwa łęczyckiego przez katolika Kacpra Maciejowskiego na rzecz jego kuzyna Jana Maciejowskiego (zm. 1588), kasztelana zawichoskiego i kalwinisty ${ }^{35}$. Dwukrotnie wakowało również starostwo ostrzeszowskie. W 1580 r. po śmierci luteranina J. Rokossowskiego nominował na nie kalwinistę Jana Bużeńskiego (zm. 1581) ${ }^{36}$. Zapewne w 1582 r. król przekazał je kalwiniście Janowi Krzysztoporskiemu (zm. 1603) ${ }^{37}$.Zmienił się również starosta wieluński: w 1584 r. po kalwiniście S. Przedborze Koniecpolskim monarcha przekazał je jego synowi i gorliwemu katolikowi Aleksandrowi Koniecpolskiemu ${ }^{38}$. Tym samym ewangelicy utrzymali swój liczbowy stan posiadania z 1576 r. z lekką przewagą nad katolikami. Jednak warto zauważyć, iż w 1584 r. utracili ważne starostwo wieluńskie, w regionie, gdzie było kilkanaście zborów ewangelickich. Uzyskanie przez nich starostwa

${ }^{31}$ Urzędnicy, t. 2, z. 2: Urzędnicy województw łęczyckiego i sieradzkiego XVI-XVIII wieku. Spisy, oprac. E. Opaliński, H. Żerek-Kleszcz, Kórnik 1993, s. 171; H. Kowalska, Mikołaj Lutomirski, PSB, t. 18, Wrocław 1973, s. 143.

${ }^{32}$ Urzędnicy, t. 2, z. 2, s. 233; Z. Libiszowska, Stanisław Przedbór Koniecpolski, PSB, t. 13, Wrocław 1968 , s. 522-523.

${ }^{33}$ Urzędnicy, t. 2, z. 2, s. 200; H. Kowalska, Jakub Rokossowski, PSB, t. 31, s. 535-536.

${ }^{34}$ Urzędnicy, t. 2, z. 2, s. 93. Nie udało mi się ustalić wyznania Piotra Dunin-Szpota, starosty piotrkowskiego, ale zapewne był on katolikiem.

${ }^{35}$ Urzędnicy, t. 2, z. 2, s. 92; I. Kaniewska, Mikołaj Maciejowski, PSB, t. 19, Wrocław 1974, s. 63.

${ }^{36}$ Urzędnicy, t. 2, z. 2, s. 200.

${ }^{37}$ Ibidem; Halina Kowalska (eadem, Jan Krzysztoporski, PSB, t. 15, Wrocław 1970, s. 569) błędnie podaje, że starostą ostrzeszowskim był od 1591 r., kiedy tak naprawdę scedował je Stanisławowi Siewierskiemu.

${ }^{38}$ Urzędnicy, t. 2, z. 2, s. 233; H. Kotatski, Aleksander Koniecpolski, PSB, t. 13, s. 511-512. PSB i Urzędnicy, t. 2, z. 2, podają różne daty śmierci Stanisława Przedbora - odpowiednio 1584 i 1588 r. Niezależnie od tego, która z nich jest prawdziwa, A. Koniecpolski był już starostą wieluńskim od $1584 \mathrm{r}$. 
łęczyckiego, gdzie zborów ewangelickich było zaledwie kilka, nie mogło zrekompensować tej straty.

Podsumowując politykę Stefana Batorego w Wielkopolsce i na Kujawach, można zauważyć, że charakteryzowała się ona generalnie utrzymaniem status quo i niepowiększaniem stanu posiadania ewangelików. W przeciwieństwie do Prus Królewskich, gdzie proporcje odwróciły się zdecydowanie na korzyść katolików, zarówno na Kujawach, jak i w województwie sieradzkim ewangelicy utrzymali w obsadzie starostw grodowych swój stan posiadania z 1576 r. W Wielkopolsce można jednak zauważyć odsuwanie ewangelików od funkcji starosty generalnego.

Na terytorium wcielonego do Korony w 1569 r. Podlasia i utworzonego wtedy województwa podlaskiego znajdowały się trzy starostwa grodowe: brańskie, drohiczyńskie oraz mielnickie. I tak starostą brańskim był niezbyt gorliwy luteranin Jan Dulski (zm.1590), kasztelan chełmiński ${ }^{39}$, starostą drohiczyńskim katolik Mikołaj Kiszka (zm. 1588), wojewoda podlaski ${ }^{40}$, natomiast starostą mielnickim kalwinista Wojciech Sawicki (zm. 1611), kasztelanic podlaski ${ }^{41}$. Żadne z nich nie wakowało w okresie panowania Stefana Batorego i stąd ewangelicy utrzymali w tym województwie przewagę.

Dzięki ustaleniom Chłapowskiego wiemy, że w Małopolsce razem z Wołyniem, Podolem, ziemią kijowską i ruską znajdowały się 34 starostwa grodowe ${ }^{42}$.Na Lubelszczyźnie zaś znajdowały się dwa starostwa grodowe i podobnie jak na Podlasiu żadne z nich nie wakowało przez całe panowanie monarchy. Starostą lubelskim był katolik Jan Tęczyński (zm. 1584), kasztelan wojnicki ${ }^{43}$. Drugie starostwo, łukowskie, dzierżył Mikołaj Mniszech (zm. 1613) ${ }^{44}$. Choć w młodości był ewangelikiem, podobnie jak bracia przeszedł na katolicyzm, zapewne w latach siedemdziesiątych XVI w. ${ }^{45}$ Tym samym w województwie z licznymi zborami ewangelickimi i aktywną ewangelicką i ariańską szlachtą proporcje odwróciły się na niekorzyść ewangelików, choć nie było to wynikiem polityki nominacyjnej monarchy, ale raczej konwersji jednego ze starostów.

${ }^{39}$ Urzędnicy, t. 8: Urzędnicy podlascy XIV-XVIII wieku. Spisy, oprac. E. Dubas-Urwanowicz i in., Kórnik 1994, s. 64; K. Lepszy, Jan Dulski, PSB, t. 5, Kraków 1939-1946, s. 461-462.

${ }^{40}$ Urzędnicy, t. 8, s. 91.

${ }^{41}$ Ibidem, s. 123; I. Kaniewska, Maciej Sawicki, PSB, t. 35, Warszawa-Kraków 1994, s. 336.

${ }^{42}$ K. Chłapowski, Starostowie w Małopolsce, s. 116-117.

${ }^{43}$ Urzędnicy, t. 4, z. 4: Urzędnicy województwa lubelskiego XVI-XVIII wieku. Spisy, oprac. W. Kłaczewski, W. Urban, Kórnik 1991, s. 51.

${ }^{44}$ Ibidem, s. 84; H. Kowalska, Mikołaj Mniszech, PSB, t. 21, Wrocław 1976, s. 486.

${ }^{45}$ PSB nie precyzuje, kiedy doszło do konwersji, ani też nie precyzuje, z którym z nurtów protestantyzmu (luteranizmem czy kalwinizmem) rodzina Mniszchów była związana. 
Na terenie województwa sandomierskiego istniało sześć starostw grodowych. W chwili koronacji monarchy nie wakowało żadne z nich, a w rękach ewangelików znajdowały się cztery. Dzierżyli je: chęcińskie - kalwinista Stanisław Dembiński (zm.1586) ${ }^{46}$; nowokorczyńskie - Mikołaj Mielecki (zm.1585), wojewoda podolski, wówczas jeszcze kalwinista ${ }^{47}$; sandomierskie - kalwinista Andrzej Filrej (zm. 1585), kasztelan lubelski ${ }^{48}$, oraz stężyckie - kalwinista Bartłomiej Żeleński (zm. 1580 ${ }^{49}$. Warto zauważyć, że obszary największych koncentracji zborów ewangelickich pokrywały się ze starostwami w posiadaniu ewangelików (Nowe Miasto Korczyn, Chęciny, Sandomierz, Stężyca). Starosta chęciński S. Dembiński słynął z agresywnego promowania kalwinizmu na swoim terytorium ${ }^{50}$, a starosta nowokorczyński M. Mielecki przychylnie patrzył na rozwój reformacji na terenie swojego starostwa ${ }^{51}$.

Obydwa starostwa dzierżone w 1576 r. przez katolików pozostały w tych samych rękach do końca panowania Batorego, podobnie jak starostwo chęcińskie w posiadaniu S. Dembińskiego. Tym samym więc polityka nominacyjna króla ograniczała się do pozostałych trzech starostw $\mathrm{w}$ posiadaniu dysydenckim.

Jeszcze w 1577 r. starosta nowokorczyński M. Mielecki przeszedł na katolicyzm i rozpoczął akcję rewindykacji kościołów zamienionych na zbory. Po jego śmierci król mianował na jego miejsce konwertytę z kalwinizmu i gorliwego katolika Mikołaja Firleja, kasztelana bieckiego, i w ten sposób polityka rekatolicyzacji nie tylko nie ustała, ale się wzmogła ${ }^{52}$. W Stężycy, po śmierci kalwinisty B.Żeleńskiego, monarcha początkowo na jego miejsce awansował brata czeskiego Jana Ostroroga (zm. 1582) ${ }^{53}$. Jednak po jego rychłej śmierci mianował gorliwego katolika Mikołaja Zebrzydowskiego $(\mathrm{zm} .1620)^{54}$. Jeśli chodzi o starostwo sandomierskie, to po śmierci A. Firleja

${ }^{46}$ Urzędnicy, t. 4, z. 3: Urzędnicy województwa sandomierskiego XVI-XVIII wieku. Spisy, oprac. K. Chłapowski, A. Falniowska-Gradowska, Kórnik 1993, s. 31.

47 Ibidem, s. 43; H. Kowalska, Mikołaj Mielecki, PSB, t. 20, Wrocław 1975, s. 759-765.

${ }^{48}$ Urzędnicy, t. 4, z. 3, s. 117; K. Lepszy, Andrzej Firlej, PSB, t. 6, s. 474-475.

${ }^{49}$ Urzędnicy, t. 4, z. 3, s. 142.

${ }^{50}$ A. Tomczak, Walenty Dembiński (ok. 1504-1584). Kanclerz egzekucji, Toruń 1964, s. $156-158$.

${ }^{51}$ W. Urban, Z dziejów reformacji w Wiślicy, w: Et haec facienda et illa non omittenda. Profesor Wacław Urban w swych dziełach wybranych, red. A. Kądziela i in., Warszawa 2012, s. 237-242.

${ }^{52}$ Ibidem, s. 242-244; Urzędnicy, t. 4, z. 3, s. 43; K. Lepszy, Mikołaj Firlej, PSB, t. 7, Kraków 1948, s. 12-15.

${ }^{53}$ M. B. Topolska, Jan Ostroróg, PSB, t. 24, Wrocław 1979, s. 505-506; Urzędnicy, t. 4, z. 2: Urzędnicy województwa krakowskiego XVI-XVIII wieku. Spisy, oprac. S. Cynarski, A. Falniowska-Gradowska, Kórnik 1990, s. 143.

${ }^{54}$ Urzędnicy, t. 4, z. 2, s. 143. 
król mianował na jego miejsce umiarkowanego kalwinistę Stanisława Pękosławskiego (zm. 1588) - choć jego identyfikacja wyznaniowa nie jest jednoznaczna ${ }^{55}$. Tym samym pod koniec panowania monarchy sytuacja w Sandomierskiem przypominała do złudzenia tę z Prus Królewskich: katolicy dzierżyli teraz cztery z sześciu starostw, ewangelicy zaś tylko dwa, przy czym jedno znajdowało się w ich rękach jeszcze od czasów poprzedniego panowania. Znamienny jest fakt, że dwa niezwykle ważne starostwa z dużą liczbą zborów ewangelickich (Nowy Korczyn i Stężyca) na skutek nominacji monarchy znalazły się w rękach aktywnych działaczy kontrreformacyjnych, starostwo sandomierskie zaś w rękach ewangelika niezbyt zaangażowanego w sprawy wyznaniowe.

Na terenie województwa krakowskiego oraz księstwa oświęcimsko-zatorskiego znajdowały się cztery starostwa grodowe. W 1576 r. w rękach katolickich znajdowało się tylko starostwo bieckie - dzierżył je przez całe panowanie Batorego Mikołaj Ligęza (zm. 1603), kasztelan czechowski ${ }^{56}$. Pozostałe trzy dzierżyli dysydenci: starostą krakowskim był kalwinista Piotr Zborowski (zm. 1580), wojewoda krakowski ${ }^{57}$, starostą sądeckim gorliwy arianin i zwolennik Stanisława Farnowskiego Stanisław Mężyk (zm. 1584), stolnik krakowski ${ }^{58}$. W silnie sprotestantyzowanym księstwie oświęcimskim starostą oświęcimskim był kalwinista Zygmunt Myszkowski (zm. 1577), burgrabia krakowski ${ }^{59}$.

Ciekawym zbiegiem okoliczności Batory miał możliwość wymiany w tym województwie wszystkich starostw obsadzonych przez dysydentów. W 1577 r. po Myszkowskim starostą oświęcimskim mianował katolika Andrzeja Tęczyńskiego (zm. 1588), wojewodę bełskiego ${ }^{60}$. Po śmierci kalwinisty Zborowskiego (1580) w 1581 r. starostwo krakowskie przekazał katolikowi kanclerzowi Janowi Zamoyskiemu ${ }^{61}$. Rok później, po wyodrębnieniu starostwa ziemskiego zatorskiego, które objął Tęczyński, starostwo grodowe oświęcimskie przekazał świeżo nawróconemu z kalwinizmu na katolicyzm Piotrowi Myszkowskiemu (zm. 1606), późniejszemu kasztelanowi lubelskiemu ${ }^{62}$. Wreszcie w 1584 r., po śmierci arianina Mężyka, na

${ }^{55}$ Nie wspomina o niej w ogóle jego biogram Henryka Kotarskiego i H. Kowalskiej, Stanisław Pękosławski, PSB, t. 25, Wrocław 1980, s. 742-744; Urzędnicy, t. 4, z.3, s. 117.

${ }^{56}$ Urzędnicy, t. 4, z. 2, s. 50-51.

${ }^{57}$ Ibidem, s. 98-99.

${ }^{58}$ Ibidem, s. 125; W. Urban, Stanisław Mężyk, PSB, t. 20, s. 515-516.

${ }^{59}$ Urzędnicy, t. 4, z. 2, s. 157; H. Kowalska, Zygmunt Myszkowski, PSB, t. 22, Wrocław 1977, s. 403-404.

${ }^{60}$ Urzędnicy, t. 4, z. 2, s. 157.

${ }^{61}$ Ibidem, s. 99.

${ }^{62}$ Ibidem, s. 157; Urzędnicy, t. 4, z. 4, s. 24; R. Żelewski, Piotr Myszkowski, PSB, t. 22 , s. 390-392. 
jego miejsce mianował katolickiego zelanta Spytka Wawrzyńca Jordana (zm. 1596), stolnika krakowskiego ${ }^{63}$. Jego nominacja oznaczała początek restytucji katolicyzmu w Nowym Sączu i okolicy: szybko wymienił on urzędników mieszczan należących do antytrynitarnego Kościoła Farnowskiego na katolików oraz z czasem doprowadził do zamknięcia zboru ariańskiego $\mathrm{w}$ mieście ${ }^{64}$. Polityka ta spotkała się z pełnym poparciem monarchy, który już w 1577 r. podczas synodu piotrkowskiego zadeklarował, że korzystając z królewskiego prawa patronatu, przeprowadzi rewizję parafii i duchownych, usuwając $\mathrm{z}$ nich heretyków i mianując $\mathrm{w}$ ich miejsce wyłącznie prawowiernych katolików ${ }^{65}$. Tym samym w ciągu swojego panowania monarcha całkowicie odsunął ewangelików i arian od starostw grodowych w Krakowskiem.

Na terytorium województwa bełskiego znajdowało się pięć starostw grodowych. Aż trzy z nich wakowały u progu 1576 r., i wszystkie po starostach ewangelikach: buskie po luteraninie Łukaszu Górce (zm.1573), wojewodzie poznańskim ${ }^{66}$, horodelskie po kalwiniście Janie Pileckim (zm. 1574), stolniku przemyskim ${ }^{67}$, oraz lubaczowskie po kalwiniście Jerzym Jazłowieckim (zm. 1575), wojewodzie ruskim ${ }^{68}$. Pozostałe dwa starostwa były w rękach katolickich i pozostały w nich przez całe panowanie króla: bełskie kanclerza J.Zamoyskiego ${ }^{69}$, a grabowieckie - prawdopodobnego katolika Piotra Cieciszewskiego ${ }^{70}$. Tym samym monarcha miał możliwość wymiany większości ze starostw w województwie. Starostwo buskie przekazał bratu zmarłego Ł. Górki, luteraninowi ${ }^{71}$ Stanisławowi, wojewodzie poznańskiemu (zm. 1592). Starostwo horodelskie otrzymał początkowo katolik Jan Gołąbek Leśniowski, ale na początku 1585 r. król przekazał je kalwiniście Janowi Sienieńskiemu (zm.1599), wojewodzie podolskiemu ${ }^{72}$. Starostwo lubaczowskie otrzymał w 1577 r. umiarkowany kalwinista Jan Płaza (zm. 1599) ${ }^{73}$. Tym samym liczba starostw w posiadaniu ewangelików pozostała bez zmian.

${ }^{63}$ Urzędnicy, t. 4, z. 2, s. 125, H. Kowalska, Spytek Wawrzyniec Jordan, PSB, t. 11, Wrocław 1965, s. 284-286.

${ }^{64}$ H. Kowalska, Spytek Wawrzyniec Jordan, s. 284.

${ }^{65}$ U. Augustyniak, op. cit., s. 43-44.

${ }^{66}$ Urzędnicy, t. 3, z. 2: Urzędnicy województwa betskiego i ziemi chełmskiej XIV-XVIII wieku. Spisy, oprac. H. Gmiterek, R. Szczygieł, Kórnik 1992, s. 97.

${ }^{67}$ Ibidem, s. 121.

${ }^{68}$ Ibidem, s. 139; R. Żelewski, Jerzy Jazłowiecki, PSB, t. 11, s. 121-123.

${ }^{69}$ Urzędnicy, t. 3, z. 2, s. 63-64.

${ }^{70}$ Ibidem, s. 109.

${ }^{71}$ Ibidem, s. 97; K. Lepszy, Stanisław Górka, PSB, t. 8, Wrocław 1960, s. 416-421.

72 Urzędnicy, t. 3, z. 2, s. 121; H. Kowalska, Jan Sienieński, PSB, t. 37, s. 183-188.

${ }^{73}$ Urzędnicy, t. 3, z. 2, s. 139; H. Kowalska, Jan Płaza, PSB, t. 26, Wrocław 1981, s. 776-777. 
Ziemia chełmska posiadała dwa starostwa grodowe: chełmskie i krasnostawskie. W chwili objęcia tronu przez monarchę tylko to ostatnie znajdowało się w rękach prawdopodobnego ewangelika Jana Mniszcha (zm. 1612) ${ }^{74}$, który dzierżył je przez cały okres panowania monarchy. Podobnie jak bracia wychowany w protestantyzmie, w latach siedemdziesiątych XVI w. przeszedł on na katolicyzm. Tym samym ewangelicy utracili to starostwo w skutek konwersji posiadacza. Starostą chełmskim był w 1576 r. katolik Aleksander Łaszcz, kasztelan czerski ${ }^{75}$. W 1582 r. za zgodą monarchy scedował je na syna Jana Łaszcza ${ }^{76}$. A zatem w chwili śmierci monarchy oba starostwa znajdowały się już w rękach katolików.

W województwie ruskim istniało sześć starostw grodowych: halickie, trembowelskie, ruskie, żydaczowskie, przemyskie i sanockie ${ }^{77}$. Rozkład wpływów katolików i ewangelików charakteryzował się tutaj w 1576 r. równowagą: trzy starostwa (termbowelskie, żydaczowskie i przemyskie) były w rękach katolików, pozostałe znajdowały się w rękach trzech kalwinistów: Hieronim Sieniawski (zm. 1582), wojewoda ruski i kalwinista, był starostą halickim ${ }^{78}$, Mikołaj Herbut (zm. 1593) był starostą generalnym ruskim ${ }^{79}$, a Jerzy Mniszech (zm. 1613), od 1582 r. kasztelan radomski, był starostą sanockim ${ }^{80}$.

Aż cztery ze starostw ruskich pozostały przez cały czas rządów Stefana Batorego w rękach tych samych osób (trembowelskie, ruskie, żydaczowskie i sanockie) - ale pomimo tego jego panowanie było okresem radykalnych zmian w pozycji ewangelików i katolików w tym województwie. W 1582 r., po śmierci Sieniawskiego, starostą halickim został katolik Stanisław Włodek. Polityka nominacyjna króla nie była jedynym powodem zmian w strukturze wyznaniowej: w 1583 r. załamany śmiercią syna

${ }^{74}$ Urzędnicy, t. 3, z. 2, s. 209-210; J. Urwanowicz, Jan Mniszech, PSB, t. 21, s. 461-462.

${ }^{75}$ Urzędnicy, t. 3, z. 2, s. 191; I. Kaniewska, Aleksander Łaszcz, PSB, t. 18, s. 259-260.

${ }^{76}$ Urzędnicy, t. 3, z. 2, s. 191.

77 Urzędnicy, t. 3, z. 1: Urzędnicy województwa ruskiego XIV-XVIII wieku. Spisy, oprac. K. Przyboś, Wrocław 1987, passim.

${ }^{78}$ Ibidem, s. 68-69; M. Plewczyński, Hieronim Sieniawski, PSB, t. 37, s. 119-121. Jego biogram w PSB przypisuje mu konwersję na katolicyzm „na krótko przed śmiercią”, bez podania szczegółów ani daty. Pomijając brak możliwości weryfikacji prawdziwości takich konwersji, przemawia przeciwko niej fakt, że nuncjusz Alberto Bolognetti pisał w 1582 r. tylko o konwersji dwóch sióstr wojewody, które „oddały katolikom wiele kościołów”, przedtem zamienionych przez ich ojca na zbory kalwińskie. Nuncjusz ani słowem nie wspomina o konwersji samego wojewody, czego nie omieszkałby uczynić, pisząc o konwersjach wśród możnych. Zatem konwersję wojewody Sieniawskiego, choć była ona teoretycznie możliwa, należy uznać raczej za pobożne życzenie jego świeżo nawróconej na katolicyzm rodziny i wdowy-katoliczki, zob. Monumenta Poloniae Vaticana (dalej: MPV), t. 6, Kraków 1938, s. 433.

${ }^{79}$ Urzędnicy, t. 3, z. 1, s. 152.

${ }^{80}$ Ibidem, s. 294; E. Opaliński, Jerzy Mniszech, PSB, t. 21, s. 465-467. 
M. Herbut, starosta ruski, poddał się namowom jezuity Herbsta i przeszedł na katolicyzm. Już po konwersji awansował na kasztelana halickiego $^{81}$. Nieco wcześniej - być może nawet już u progu panowania Batorego - na katolicyzm przeszedł Jerzy Mniszech, starosta sanocki - i stał się gorliwym katolikiem ${ }^{82}$. Tym samym, wskutek $\mathrm{w}$ równym stopniu polityki nominacyjnej władcy, jak i konwersji na katolicyzm, u schyłku panowania władcy wszystkie starostwa grodowe w województwie znajdowały się w rękach katolickich.

Na rozległym terenie Podola i województwa bracławskiego znajdowały się zaledwie trzy starostwa grodowe: kamienieckie w województwie podolskim oraz bracławskie i winnickie w województwie bracławskim. To pierwsze przez cały okres panowania monarchy dzierżył katolik Mikołaj Brzeski ${ }^{83}$. Starostwa bracławskie i winnickie znajdowały się w początkowo posiadaniu tej samej osoby, prawosławnego kniazia Bohusza Koreckiego (zm. 19 VIII 1576), wojewody wołyńskiego ${ }^{84}$. Po jego śmierci oba starostwa z nadania monarchy otrzymał Jerzy Struś (zm.1607), późniejszy kasztelan halicki ${ }^{85}$. Ustalenie jego wyznania jest trudne - sprawy tej w ogóle nie porusza jego biogram w PSB. Są pewne przesłanki, by uważać go za dysydenta, zapewne kalwinistę, choć mógł być i arianinem - niezależnie jednak od wyznania nie był osobą zbyt religijną ${ }^{86}$. Tym samym ewangelicy zwiększyli swój udział na tych ziemiach, ale co znamienne, stało się to kosztem prawosławnych.

W województwie wołyńskim istniały trzy starostwa grodowe, które w 1576 r. znajdowały się w rękach dwóch prawosławnych i jednego katolika: krzemienieckie dzierżył katolik, kniaź Janusz Zbaraski (zm. 1608) ${ }^{87}$, łuckie prawosławny kniaź B. Korecki (zm.19 VIII 1576) ${ }^{88}$, włodzimierskie zaś

${ }^{81}$ R. Żelewski, Mikołaj Herbut, PSB, t. 9, Wrocław 1960-1961, s. 447-449.

${ }^{82}$ E. Opaliński, Jerzy Mniszech, s. 466.

${ }^{83}$ Urzędnicy, t. 3, z. 3: Urzędnicy podolscy XIV-XVIII wieku. Spisy, oprac. E. Janas i in., Kórnik 1998, s. 132.

${ }^{84}$ K. Chłapowski, Starostowie w Małopolsce, s. 148, 151; J. Maciszewski, Bohusz Korecki, PSB, t. 14, Wrocław 1968, s. 58-59.

${ }^{85} \mathrm{~K}$. Chłapowski, Starostowie w Małopolsce, s. 148, 151.

${ }^{86}$ J. Byliński, Jerzy Struś, PSB, t. 44, Warszawa-Kraków 2006, s. 463-467. Fakt pochowania ojca Stanisława (zm. 1567) w kopcu (s. 477) w zwyczaju typowym dla arian oraz koligacje rodzinne - matka Anna z Potockich była niewątpliwą ewangeliczką, a szwagierka Zofia z Orzechowskich była kalwinistką (albo arianką) - mogą wskazywać na protestanckie wyznanie starosty. Zastanawia także brak jakichkolwiek katolickich fundacji kościelnych tej rodziny. Wszystko to pozwala przypuszczać, iż Strusiowie byli wyznania ewangelickiego.

${ }^{87}$ Urzędnicy, t. 3, z. 5: Urzędnicy wołyńscy XIV-XVIII wieku. Spisy, oprac. M. Wolski, Kórnik 2007, s. 63.

${ }^{88}$ Ibidem, s. 97. 
prawosławny kniaź Konstanty Wasyl Ostrogski (zm. 1608), wojewoda kijowski ${ }^{89}$. Za panowania Batorego wakowało (aż dwukrotnie) tylko jedno z nich - starostwo łuckie. Początkowo król mianował na nie Aleksandra Markowicza Żurawnickiego, którego wyznania nie udało mi się ustalić ${ }^{90}$. Po jego śmierci w 1580 r. starostwo łuckie objął kalwinista kniaź Aleksander Proński (zm. 1595) ${ }^{91}$. Tym samym w województwie pod koniec panowania monarchy ustaliła się równowaga między katolikami, prawosławnymi i ewangelikami. Jednak, podobnie jak w ziemi bracławskiej, poprawa stanu posiadania ewangelików odbyła się kosztem prawosławnych, a nie katolików.

W województwie kijowskim znajdowały się trzy starostwa grodowe: żytomierskie, owruckie i kijowskie, z których to ostatnie dzierżył z urzędu zawsze wojewoda kijowski ${ }^{92}$. U progu 1576 r. urząd starosty żytomierskiego piastował wyznawca prawosławia kniaź Michał Aleksandrowicz Czartoryski (zm. 1582) ${ }^{93}$. Starostą owruckim był wówczas prawosławny Michał Myszka Warkowski (zm. 1604), kasztelan wołyński ${ }^{94}$. Oba starostwa zmieniły właścicieli w czasie panowania monarchy - w 1578 r. król wyraził zgodę na cesję starostwa owruckiego przez Michała na rzecz syna (wtedy jeszcze prawosławnego) Abrahama Myszki Warkowskiego (zm. 1608) ${ }^{95}$. W 1582 r. po śmierci kniazia Czartoryskiego starostwo żytomierskie trafiło do (najprawdopodobniej) prawosławnego Szymona Denisko Matwiejewskiego ${ }^{96}$. Starostą kijowskim pozostał przez całe panowanie monarchy gorliwy obrońca prawosławia, książę K.W. Ostrogski ${ }^{97}$. Województwo kijowskie było więc jedynym w Koronie, gdzie przez całe panowanie monarchy żadnego ze starostw nie pełnili ani katolicy, ani ewangelicy.

\section{Podsumowanie}

W kontekście polityki nominacyjnej Batorego niezwykle interesujący jest przypadek starostwa warszawskiego położonego na katolickim Mazowszu,

${ }^{89}$ Ibidem, s. 121-122.

${ }^{90}$ Ibidem, s. 97.

${ }^{91}$ Ibidem, s. 98; R. Żelewski, Aleksander Fryderyk Proński, PSB, t. 28, Wrocław 1985, s. 507-509.

${ }^{92}$ Urzędnicy, t. 3, z. 4: Urzędnicy województwa kijowskiego i czernihowskiego XV i XVIII wieku. Spisy, oprac. E. Janas, W. Kłaczewski, Kórnik 2002, s. 7.

${ }^{93}$ Ibidem, s. 139.

${ }_{94}$ Ibidem, s. 99; J. Wiśniewski, Michał Myszka, PSB, t. 22, s. 366-368. Pod koniec życia przeszedł wraz z rodziną na katolicyzm i poparł unię brzeską.

${ }^{95}$ Urzędnicy, t. 3, z. 4, s. 99.

${ }^{96}$ Ibidem, s.139.

${ }^{97}$ Ibidem, s. 67. 
ale obejmującego rosnącą w znaczenie i prestiż Warszawę, gdzie wbrew uparcie podnoszonym przez mazowiecką szlachtę tezom, podobnie jak w reszcie państwa, obowiązywała Konfederacja Warszawska.W 1576 r. wakujące po zamarłym w 1574 r. kalwiniście Zygmuncie Wolskim starostwo monarcha powierzył swojemu faworytowi i umiarkowanemu ewangelikowi reformowanemu Jerzemu Niemście ${ }^{98}$. Nowy starosta uznał, zgodnie z postanowieniami Konfederacji Warszawskiej, że warszawscy mieszczanie ewangelicy oraz przyjeżdżający na obrady sejmu dysydenci winni mieć własny budynek kościelny do odprawiania nabożeństw. Dotychczas bowiem korzystali z ze stołecznego dworu kalwińskiej rodziny Gostomskich. Budowa własnego kościoła miała też niewątpliwie wzmocnić prestiż i legalność protestantyzmu w tym ważnym dla Rzeczypospolitej mieście. W 1579 r. starosta Niemsta wyznaczył plac i rozpoczął budowę kościoła.Jednak specjalnym listem spod Pskowa monarcha nakazał wstrzymanie budowy (1579). Niemsta i ewangelicy nie dawali za wygraną i ponownie podjęli budowę kościoła przed sejmem w 1581 r., licząc na poparcie tłumnie zgromadzonej na sejmie dysydenckiej szlachty, której obecność rzeczywiście początkowo zapewniła budowie spokój.Jednak już zakończeniu obrad sejmu - i wyjeździe protestanckiej szlachty z miasta - podburzony przez mazowiecką szlachtę tłum przy cichym poparciu królowej Anny Jagiellonki i kanclerza J. Zamoyskiego zdemolował budowę i zniszczył budynek $(1581)^{99}$. Nuncjusz Alberto Bolognetti żądał wprost od monarchy usunięcia Niemsty ze stanowiska i mianowania na jego miejsce gorliwego katolika ${ }^{100}$. Do wznowienia budowy nie doszło, gdyż Niemsta zmarł na początku $1583 \mathrm{r}$. Natychmiast po jego śmierci dyplomata papieski rozpoczął energiczne zabiegi, by jego następcą został katolik, co też monarcha mu obiecał ${ }^{101}$. Nowym starostą warszawskim został jeszcze przed kwietniem 1583 r. Bartłomiej Zaliwski, którego uszczęśliwiony nuncjusz określał jako „bonissimo cattolico et devotissimo" ${ }^{102}$. Nie poprzestając na samej nominacji gorliwego katolika, władca wydał mandat, w którym zakazywał mieszczanom odbywania jakichkolwiek zebrań heretyckich w Warszawie pod groźbą wygnania $\mathrm{z}$ miasta ${ }^{103}$.

Wymowne jest to, iż właśnie rok 1582 jest tym, po którym monarcha na starostów grodowych w Koronie przestał mianować ewangelików (z je-

\footnotetext{
${ }^{98}$ H. Kowalska, Jerzy Niemsta, PSB, t. 23, Wrocław 1978, s. 35-37.

${ }_{99}$ W. Smoleński, Szkice z dziejów szlachty mazowieckiej, Kraków 1908, s. 106.

${ }^{100}$ MPV, t. 5, Kraków 1923-1933, s. 455-464.

101 MPV, t. 6, s. 85, 88.

102 Ibidem, s. 221.

103 G. Schramm, Problem Reformacji $w$ Warszawie $w$ XVI wieku, PH 54, 1963, 4,
} s. $566-568$. 
dnym wyjątkiem). Jednocześnie ten sam rok jest cezurą, od której starostami król mianuje gorliwych działaczy kontrreformacyjnych i rozpoczyna się proces powolnego usuwania ewangelików z posiadłości królewskich. O tym, że konwersja na katolicyzm pomagała w karierze senatorskiej już za czasów „króla niemalowanego”, świadczy fakt, iż to właśnie jemu zawdzięczają przyśpieszenie lub rozwój kariery słynni konwertyci z protestantyzmu: J. Zamoyski, M. Firlej (na katolicyzm przeszli jeszcze za panowania Zygmunta II Augusta), Lew Sapieha, Mikołaj Radziwiłł „Sierotka”, A. Koniecpolski, P. Myszkowski, Albrecht Radziwiłł i inni. Monarcha owszem, awansował koroniarzy-protestantów do senatu, ale zazwyczaj poprzestawali oni - z pewnymi wyjątkami - na krzesłach kasztelańskich, które powoli stawały się w Koronie „protestanckim szklanym sufitem”.

Generalnie, trend za panowania Stefana Batorego był powolny, ale nieubłagany: dysydenci byli systematycznie odsuwani od funkcji starostów grodowych w Koronie. Było to widoczne i groźne szczególnie w ośrodkach, gdzie reformacja była silna: Sądecczyzna, ziemia oświęcimska, starostwa nowokorczyńskie, stężyckie, wieluńskie czy województwo pomorskie. Na skutek nominacji monarchy starostowie dysydenci zniknęli z Krakowskiego i ziemi ruskiej, a w Sandomierskiem i Prusach Królewskich ich stan posiadania uległ wyraźnemu ograniczeniu. Po 1582 r., z wyjątkiem nominacji J. Sienieńskiego na starostę horodelskiego, monarcha nie mianował już w Koronie żadnego starosty grodowego ewangelika i wręcz zaostrzył swój stosunek do praw innowierców, o czym świadczy np. sprawa nabożeństw kalwińskich w warszawskim dworze Stanisława Gostomskiego ${ }^{104}$. Właśnie w 1583 r. mamy wyraźną obietnicę udzieloną nuncjuszowi i zrealizowaną przez monarchę, że na starostwo warszawskie (po kalwiniście Niemście) i województwo ruskie (wakujące po śmierci kalwinisty H. Sieniawskiego) awansuje tylko katolika: „W tej sprawie ponowiłem u Jego Królewskiej Mości prośbę, by na to wakujące od kilku lat województwo mianować katolika, który zapewnił mnie, iż tak właśnie zamierza uczynić"105. Tym samym pierwszym monarchą, który uzależniał nominację od wyznania, nie był wcale Zygmunt III Waza ${ }^{106}$, ale Stefan Batory.

W chwili jego śmierci liczba starostów dysydentów spadła z 27 do 18, z których aż 6 było mianowanych przez jego poprzedników. Arianie z tej grupy zniknęli całkowicie. Procentowo - nie licząc Mazowsza - liczba

${ }^{104}$ Ibidem, s. 568.

105 „In questo proposito rinovali a S. Mta I'instanza di nar quell palatino che pur anco vaca ad un cattolico, il che dice voler fare", MPV,t. 6, s. 433. Ostatecznie w 1585 r. król wojewodą ruskim mianował katolika Stanisława Żółkiewskiego (zm. 1588), Urzędnicy, t. 3, z. 1, s. 161 .

${ }^{106}$ L. Jarmiński, op. cit., s. 31. 
starostw w posiadaniu ewangelików spadła z ok. $52 \%$ do ok. $34 \%$. Jest to o tyle ciekawe, że jeśli u progu panowania monarchy procentowo liczba starostów ewangelików była podobna do senatorów ewangelików, to już w chwili jego zgonu starostów dysydentów było dużo mniej niż senatorów dysydentów. Można więc z pewną ostrożnością stwierdzić, że polityka nominacyjna starostw grodowych była zwiastunem polityki nominacyjnej w senacie i schyłku wpływu dysydentów w izbie wyższej za panowania kolejnego władcy.

Tabela. Zmiana udziału starostów dysydentów w okresie panowania Stefana Batorego

\begin{tabular}{|c|c|c|c|}
\hline \multirow{2}{*}{$\begin{array}{c}\text { Województwa lub } \\
\text { ziemie }\end{array}$} & \multicolumn{2}{|c|}{\begin{tabular}{|} 
Starostwa w posiadaniu dysydentów \\
w stosunku do ogólnej liczby starostw
\end{tabular}} & \multirow{2}{*}{$\begin{array}{l}\text { Zmiany udziału } \\
\text { ewangelików } \\
\text { w ogólnej liczbie } \\
\text { starostów }\end{array}$} \\
\hline & $\begin{array}{c}\text { w chwili koronacji } \\
\text { króla }\end{array}$ & $\begin{array}{l}\text { w chwili } \\
\text { śmierci króla }\end{array}$ & \\
\hline Prusy Królewskie & $2 \mathrm{z} 3$ & $1 \mathrm{z} 3$ & $-50 \%$ \\
\hline Wielkopolska & $1 \mathrm{z} 3$ & $1 \mathrm{z} 3$ & - \\
\hline Kujawy & $4 \mathrm{z} 4$ & $3 \mathrm{z} 4$ & $-25 \%^{*}$ \\
\hline $\begin{array}{l}\text { Woj. sieradzkie, } \\
\text { łęczyckie i ziemia } \\
\text { wieluńska }\end{array}$ & 3 z 5 & 3 z 5 & - \\
\hline Podlasie & $2 \mathrm{z} 3$ & $2 \mathrm{z} 3$ & - \\
\hline Ziemia lubelska & $1 \mathrm{z} 2$ & $0 \mathrm{z} 2$ & $-100 \%^{*}$ \\
\hline Woj. sandomierskie & $4 \mathrm{z} 6$ & $2 \mathrm{z} 6$ & $-50 \%$ \\
\hline Woj. krakowskie & $3 \mathrm{z} 4$ & $0 \mathrm{z} 4$ & $-100 \%$ \\
\hline Woj. bełskie & $3 \mathrm{z} 5$ & $3 \mathrm{z} 5$ & - \\
\hline Ziemia chełmska & $1 \mathrm{z} 2$ & $0 \mathrm{z} 2$ & $-100 \%^{*}$ \\
\hline Woj. ruskie & $3 \mathrm{z} 6$ & $0 \mathrm{z} 6$ & $-100 \%$ \\
\hline Podole i woj. bracławskie & $0 \mathrm{z} 3$ & $2 \mathrm{z} 3$ & $+100 \%$ \\
\hline Wołyń i Kijowszczyzna & $0 \mathrm{z} 6$ & $1 \mathrm{z} 6$ & $+100 \%$ \\
\hline $\begin{array}{l}\text { Ogółem } \\
\text { w \% }\end{array}$ & $\begin{array}{l}27 \text { z } 52 \\
51,92 \%\end{array}$ & $\begin{array}{l}18 \text { z } 52 \\
34,61 \%\end{array}$ & $-17,3 \%$ \\
\hline
\end{tabular}

*Jeden ze starostów ewangelików przeszedł na katolicyzm.

Jak widać z tabeli, w czasie panowania Stefana Batorego ewangelicy stracili 9 starostw, co stanowi prawie 17\% wszystkich urzędów starościńskich. 


\section{Religion as a factor in king Stefan Batory's nomination policy in the Polish Crown lands - the beginning of the Counter-Reformation?}

For many years Stefan Batory was viewed as a religiously tolerant monarch who, unlike his successor Zygmunt III Waza, promoted nobles without discrimination based on their religion. The article examines Batory's so-far overlooked nomination policies to the rank of starosta grodowy. This was an office responsible for enforcing the courts' decrees in their respective localities. It became especially important in the decade after the king's death, when the Roman Catholic church relied on their assistance to regain possession of churches turned over for Protestant worship in the 1550s and 1560s.

The article looks at the politics of nomination from the time of the monarch's coronation (1 May 1576) to that of his death on 12 December 1586 . Overall 52 offices and their respective office holders are analyzed in the land of the Polish Crown (Korona), excluding the heavily Roman Catholic province of Masovia (Mazowsze). The Autor contends that in his nomination policy the King worked to limit the number of Protestant office holders. In fact, his reign saw a dramatic reversal of Protestant starostas in Lesser Poland. From a clear majority of office holders they became a minority. Many of the new starostas were fresh converts to Roman Catholicism and dedicated Counter-Reformation activists, and appointed to areas that were heavily Protestantized. Indeed, it was Stefan Batory who became the first monarch to limit advancement to certain posts only to Roman Catholic nobility. The author shows that after 1582 (with one exception) he did not nominate a single new Protestant starosta. By the end of his reign Protestant starostas shrunk form $52 \%$ to just $34 \%$, a third of whom were nominated by his predecessor. Thus, the king's deliberate and consistent policy of favouring Roman Catholics in the lands of the Crown should be seen as the beginning of the Counter-Reformation in Commonwealth of Two Nations.

Kazimierz Bem 